\title{
Delayed Androgen Treatment Prolongs Survival in Murine Lupus
}

\author{
J. R. Roubinian, N. Talal, J. S. Greenspan, J. R. Goodman, and P. K. Siiteri, \\ Section of Clinical Immunology, Veterans Administration Hospital, and \\ Departments of Medicine, Oral Medicine, Surgery, Pediatrics, and Obstetrics \\ and Gynecology, University of California, San Francisco, California 94143
}

\begin{abstract}
A B S T RACT Female NZB/NZW $F_{1}$ mice were treated as adults with 5 - $\alpha$-dihydrotestosterone powder packed into subcutaneous implants. Two treatment protocols were followed: $(a)$ 3-mo-old mice received $6 \mathrm{mg}$ of androgen, and (b) 6-mo-old mice were castrated and given $12 \mathrm{mg}$ of androgen. Sham females received empty implants. Mice were followed monthly for survival, for antibodies to DNA and polyadenylic acid, and for renal histopathology.

The percent survival at 11 mo was $74 \%$ for mice treated at 3 mo, compared to $11 \%$ for the sham controls, and $100 \%$ for mice treated at 6 mo, compared to $20 \%$ for their sham controls. Androgen-treated mice had less immune complex glomerulonephritis as determined by immunofluorescent and electron microscopy. Surprisingly, treated mice had no significant sustained reduction in antibodies to DNA although they had reduced antibodies to polyadenylic acid.

These results suggest that androgens can still prolong survival and reduce immune complex deposition even when treatment is delayed to an age when disease is relatively established. After delayed androgen treatment, mice survive despite the presence of high levels of IgG antibodies to DNA.
\end{abstract}

\section{INTRODUCTION}

$\mathrm{NZB} / \mathrm{NZW} \mathrm{F}_{1}$ hybrid mice $(\mathrm{B} / \mathrm{W})^{1}$ mice are considered a laboratory model for systemic lupus erythematosus (1). Genetic (2), viral (3), and immunologic factors (4) are implicated in their disease. Female $\mathrm{B} / \mathrm{W}$ mice spontaneously develop, after 4 mo of age, a lupus-like dis-

Received for publication 26 July 1978 and in revised form 2 January 1979.

${ }_{1}$ Abbreviations used in this paper: $\mathrm{B} / \mathrm{W},(\mathrm{NZB} \times \mathrm{NZW}) \mathrm{F}_{1}$ hybrid mice; PBS, phosphate-buffered saline; Poly A, polyadenylic acid; SLE, systemic lupus erythematosus; Slp, the sex-limited protein variant of Ss; Ss, the analogue of human C4. order characterized by the formation of antibodies to DNA and to polyadenylic acid (Poly A), the development of immune complex glomerulonephritis and death between 8 and 12 mo of age. Males develop a similar disease later in life.

We reported that prepubertal castration of male $B / W$ mice caused an essentially female pattern of disease with $100 \%$ mortality at $11 \mathrm{mo}(5)$. By contrast, prepubertal castration of female $B / W$ mice had no effect on mortality, although it markedly reduced the development of IgG antibodies to Poly A. We subsequently showed that prepubertal castration combined with the administration of either 5 - $\alpha$-dihydrotestosterone or estradiol-17- $\beta$ had profound effects on the autoimmune disease. Mice receiving androgen showed improved survival, reduced anti-nucleic acid antibodies, and less evidence of glomerulonephritis as determined by light, immunofluorescent, and electron microscopy. By contrast, opposite effects were observed in castrated mice receiving estrogen (6).

These results suggest that sex hormones modulate the expression of autoimmunity in $\mathrm{B} / \mathrm{W}$ mice, with androgens exerting a protective influence, whereas estrogens accelerate disease process. Similar conclusions have been reached by other investigators $(7,8)$. Because these experiments were undertaken in animals less than 1 mo of age, it was important to study the effects of delayed androgen treatment initiated at a time when autoimmune disease was more developed. We now report the ability of delayed androgen treatment, started at 3 and 6 mo of age, to prolong survival in female $\mathrm{B} / \mathrm{W}$ mice. An interesting feature of these experiments is the fact that mice are surviving even though there is no significant reduction in levels of anti-DNA antibodies.

\section{METHODS}

Mice. B/W mice were from our colony at the University of California Vivarium, San Francisco, Calif,, and they were 
maintained at the Fort Miley Veterans Administration Hospital, San Francisco, Calif.

Hormone treatment. Mice were given 5- $\alpha$-dihydrotestosterone powder packed into silastic tubes, which were then implanted subcutaneously. Control mice received empty implants. This procedure permits a slow release of hormone producing physiologic levels of testosterone for 6-8 mo (6). Two different treatment protocols were followed. In the first protocol, $43 \mathrm{~B} / \mathrm{W}$ females received $6 \mathrm{mg}$ of androgen at $3 \mathrm{mo}$ of age. There were $27 \mathrm{~B} / \mathrm{W}$ females that received sham implants and served as the control group in this experiment. In the second protocol, $19 \mathrm{~B} / \mathrm{W}$ females were castrated and given $12 \mathrm{mg}$ of estrogen at $6 \mathrm{mo}$ of age. An additional $20 \mathrm{~B} / \mathrm{W}$ female control mice underwent sham surgery and received an empty implant at 6 mo.

Additional groups of mice were established in the same manner for study of renal histopathology. In this way, there was no necessity to remove mice for examination of the kidneys from the studies measuring survival and autoantibodies.

Oophorectomy was performed through a midline abdominal incision. Ovaries were identified and removed by electrocautery. The incision was closed with 6-0 silk suture material. Experimental animals were distinguished from sham-operated mice by ear-tagging.

Observation. Mice were observed weekly. Mortality in experimental and control groups was tabulated in $2 \times 2$ contingency tables, and evaluated by chi-square analysis with Yates modification.

Fractionation of serum. Blood was collected from mice at monthly intervals. Blood was collected by orbital sinus bleeding, allowed to clot at room temperature for $1 \mathrm{~h}$, and left at $4^{\circ} \mathrm{C}$ overnight. Serum was separated by centrifugation at 1,200 $\mathrm{g}$ for $10 \mathrm{~min}$. Serum samples from hormone-treated and shamoperated mice were pooled separately. $200 \mu \mathrm{l}$ of the pooled serum samples was subjected to ultracentrifugation in a $10-35 \%$ linear sucrose density gradient $(0.15 \mathrm{M} \mathrm{NaCl}, \mathrm{pH} 8.0)$ as previously described (6). Three proteins of known sedimentation constants were run in companion gradient and served as reference markers. Gradients were collected dropwise into $\mathbf{4 0}$ fractions. Peak fractions were tested for immunoglobulin content. In the $19 S$ region (fractions 10-20) only activity against $\mu$-chain could be detected by Ouchterlony analysis, whereas in the $7 \mathrm{~S}$ region (fractions 20-30), activity against $\gamma$-chain, but not $\mu$-chain, was present. Each fraction was analyzed for antibody to DNA and Poly A. To determine that the binding was caused by immunoglobulin, monospecific rabbit anti-mouse $\mu$-chain and anti-mouse $\boldsymbol{\gamma}$-chain antisera were added to peak fractions from $19 S$ and $7 S$ regions, respectively. Anti- $\mu$ inhibited DNA binding between 77 and
$100 \%$, whereas anti- $\gamma$ inhibited binding between 66 and $78 \%$. Addition of goat anti-mouse albumin to these gradient fractions had no inhibitory effect.

Anti-DNA and anti-Poly A assays. Antibodies to DNA and Poly A were determined separately with a cellulose ester filter radioimmunoassay (9). The radioactive nucleic acids were double-stranded DNA ( $\left[{ }^{3} \mathrm{H}\right] \mathrm{DNA}$ ) from KB cells (obtained from Electro-Nucleonics Inc., Fairfield, N. J.), and $\left[{ }^{3} \mathrm{H}\right]$ polyriboadenylic acid (Miles Laboratories Inc., Elkhart, Ind.). The latter is a synthetic single-stranded RNA. The radioactive antigens (750 cpm/7.74 ng Poly A; $700 \mathrm{cpm} / 3 \mathrm{ng}$ DNA) were incubated with decomplemented $50-\mu$ l aliquots of each fraction for $30 \mathrm{~min}$ at $37^{\circ} \mathrm{C}$ followed by an overnight incubation at $4^{\circ} \mathrm{C}$. The antigen-antibody complexes were collected onto cellulose ester filters (Millipore Corp., Bedord, Mass.). The filters were placed in counting vials and covered with $10 \mathrm{ml}$ of Liquifluor-toluene scintillation medium (Liquifluor, New England Nuclear, Boston, Mass.). Radioactivity was determined in a Packard liquid scintillation counter (Packard Instrument Co., Inc., Downers Grove, Ill). The radioactive binding profiles revealed clear distribution into $7 \mathrm{~S}$ and $19 \mathrm{~S}$ peaks of activity after sucrose gradient fractionation. The radioactivity representing the fractionated $7 \mathrm{~S}$ and $19 \mathrm{~S}$ peaks within a single gradient were added and compared for total binding activity. The results are expressed as nanograms radioactive antigen bound per $0.2 \mathrm{ml}$ of serum.

Reproducibility and analysis of data. To establish the reproducibility of our assay technique and the divergence found in age-matched mice, pooled serum samples from intact, shamoperated and variously treated male and female mice were subjected to sucrose gradient ultracentrifugation and assayed for antibodies to DNA. Ages of these mice ranged from 12 to $36 \mathrm{wk}$. In all cases, procedures were performed by the same technician, and the radioactive DNA employed was from the same lot. A number of age-matched pooled samples were assayed on the same day, then reassayed 1 mo later. The range of variation from the mean for the total anti-DNA binding in the $19 \mathrm{~S}$ region was between 1.0 and $14 \%$; in the $7 \mathrm{~S}$ region variations ranged from 0.2 to $7.1 \%$. A minimum variation of $13 \%$ in the immunoglobulin (Ig) M and $8 \%$ in the IgG total binding activity from age- and sex-matched, sham-operated controls was required for a result to be considered significant; these values represent $2 \mathrm{SD}$ from the mean.

To determine the biologic variability within each group of mice, subgroups were created by pooling sera in the following way: mice receiving androgen from $3 \mathrm{mo}$ of age were divided into six subgroups, whereas sham mice were divided into three subgroups. In addition, the biologic variability from one mouse to another was determined by comparing levels of antibodies to DNA and Poly A, and the extent of immune complex

TABLE I

Effect of Delayed Androgen Treatment on Cumulative Mortality in $\mathrm{B} / \mathrm{W}$ Female Mice

\begin{tabular}{lccccccccc}
\hline & & \multicolumn{8}{c}{ Mortality at various ages, mo } \\
\cline { 3 - 10 } \multicolumn{1}{c}{ Procedure } & mice & 4 & 5 & 6 & 7 & 8 & 9 & 10 & 11 \\
\hline & & & & & & $\%$ & & & \\
$\begin{array}{l}\text { Sham } \\
\begin{array}{l}\text { Androgen treatment } \\
\text { at 3 mo }\end{array}\end{array}$ & 27 & 0 & 4 & 15 & 30 & 48 & 63 & 78 & 89 \\
\hline
\end{tabular}

${ }^{*} P<0.05$ (compared to sham group). 
TABLE II

Effect of Castration and Delayed Androgen Treatment on Cumulative Mortality in B/W Female Mice

\begin{tabular}{|c|c|c|c|c|c|c|c|}
\hline \multirow[b]{2}{*}{ Procedure } & \multirow{2}{*}{$\begin{array}{l}\text { No. of } \\
\text { mice }\end{array}$} & \multicolumn{6}{|c|}{ Mortality at various ages, mo } \\
\hline & & 6 & 7 & 8 & 9 & 10 & 11 \\
\hline & & \multicolumn{6}{|c|}{$\%$} \\
\hline Sham & 20 & 0 & 15 & 30 & 55 & 65 & 80 \\
\hline $\begin{array}{l}\text { Androgen treatment and } \\
\text { castration at } 6 \mathrm{mo}\end{array}$ & 19 & 0 & 0 & 0 & $0 *$ & $0 *$ & $0^{*}$ \\
\hline
\end{tabular}

${ }^{*} P<0.05$ (compared to sham group).

deposition in renal glomeruli, in three sham and three androgen-treated mice. The latter were treated from 3 mo and sacrificed at 9 mo of age.

Histopathology. At monthly intervals between 6 and 9 mo of age, sham and treated mice were selected at random and sacrificed. Kidneys were removed and studied by light and electron microscopy, and immunofluorescence was performed to ascertain the presence and extent of immune complex deposition. These examinations were performed before breaking the specimen code. For light microscopy, 4- $\mu \mathrm{m}$ paraffin sections stained with hematoxylin and eosin.

Direct immunofluorescence for glomerular immunoglobulin deposition. Cryostat sections, $5 \mu \mathrm{m}$ thick, were cut and picked up on Formolgelatin-coated slides (Formol, Data Instruments Co., Sepulveda, Calif.), air-dried for $30 \mathrm{~min}$, and washed twice for $15 \mathrm{~min}$ in phosphate-buffered saline (PBS) at $\mathrm{pH}$ 7.2. The slides were placed in a moist chamber, covered with antiserum, and incubated for $30 \mathrm{~min}$ at room temperature in the dark. Fluorescein isothiocyanate-conjugated rabbit polyvalent anti-mouse Ig (Behring Diagnostics, Sommerville,
N. J.; lot 656, F/P 2:8) was used at a titer of 1:20. Slides were rinsed quickly in PBS and washed twice for $15 \mathrm{~min}$ in PBS with gentle agitation, rinsed in distilled water, and mounted in glycerin-PBS. Coated sections were examined with a Wild fluorescence microscope (Wild Heerbrugg Instruments, Inc., Farmingdale, N. Y.). The brightness and extent of glomerular immunoglobulin immunofluorescence was graded on a scale of $0-6$ by two observers who were calibrated against each other and against sections from standard specimens used in our laboratory.

Electron microscopy. Mouse kidneys were cut immediately in cold $1 \%$ glutaraldehyde in $0.1 \mathrm{M}$ cacodylate buffer, $\mathrm{pH}$ 7.3. After $1.5 \mathrm{~h}$ fixation at room temperature, they were fixed additionally in $1 \%$ osmium tetroxide in $0.1 \mathrm{M}$ cacodylate buffer ( $\mathrm{pH}$ 7.3) for $45 \mathrm{~min}$. The specimens were dehydrated with alcohol and propylene oxide, infiltrated with EponAraldite plastic (Epon, Shell Chemical Co., Houston, Tex.; Araldite, CIBA-Geigy Corp., Ardsley, N. Y.), and polymerized at $75^{\circ} \mathrm{C}$. Ultrathin sections were cut on an LKB Ultratome III (LKB Instruments, Inc., Rockville, Md.) and stained with

TABLE III

Effect of Delayed Androgen Treatment on IgG Antibodies to DNA in B/W Female Mice

\begin{tabular}{|c|c|c|c|c|c|c|c|c|c|c|c|c|}
\hline \multirow[b]{2}{*}{ Procedure } & \multirow[b]{2}{*}{ Subgroup } & \multicolumn{11}{|c|}{ DNA Binding activity at various ages, $m o$} \\
\hline & & 5 & 6 & 7 & 8 & 9 & 10 & 11 & 12 & 13 & 14 & 15 \\
\hline & & \multicolumn{11}{|c|}{ ng DNA/0.2 $\mathrm{ml} \mathrm{serum}$} \\
\hline $\begin{array}{l}\text { Sham-operated controls } \\
\text { at } 3 \text { mo }\end{array}$ & $\begin{array}{c}\text { A } \\
\text { B } \\
\text { C } \\
\text { Mean } \pm \text { SD }\end{array}$ & 21 & 27 & $\begin{array}{c}43 \\
14 \\
15 \\
24 \pm 16\end{array}$ & $\begin{array}{c}36 \\
20 \\
23 \\
26 \pm 8\end{array}$ & $\begin{array}{c}39 \\
25 \\
22 \\
29 \pm 9\end{array}$ & $\begin{array}{c}37 \\
34 \\
26 \\
32 \pm 6\end{array}$ & $\begin{array}{c}44 \\
45 \\
33 \\
41 \pm 7\end{array}$ & & & & \\
\hline $\begin{array}{l}\text { Androgen treatment } \\
\text { at } 3 \mathrm{mo}\end{array}$ & $\begin{array}{c}\text { A* }^{*} \\
\text { B } \\
\text { C } \\
\text { D } \\
\text { E } \\
\text { F } \\
\text { Mean } \pm \text { SD }\end{array}$ & 9 & 26 & $\begin{array}{c}41 \\
10 \\
7 \\
16 \\
10 \\
13 \\
16 \pm 12\end{array}$ & $\begin{array}{c}37 \\
13 \\
16 \\
19 \\
23 \\
22 \pm 9\end{array}$ & $\begin{array}{c}45 \\
36 \\
19 \\
25 \\
20 \\
29 \pm 11\end{array}$ & $\begin{array}{c}46 \\
35 \\
26 \\
24 \\
20 \\
17 \\
28 \pm 11\end{array}$ & $\begin{array}{c}49 \\
34 \\
19 \\
26 \\
24 \\
26 \\
30 \pm 11\end{array}$ & 58 & 32 & 16 & 10 \\
\hline $\begin{array}{l}\text { Sham-operated androgen } \\
\text { treatment at } 6 \text { mo }\end{array}$ & & & & 14 & 27 & 22 & 23 & 10 & & & & \\
\hline $\begin{array}{l}\text { Castration and androgen } \\
\text { treatment at } 6 \text { mo }\end{array}$ & & & & 31 & 33 & 34 & 42 & 37 & & & & \\
\hline
\end{tabular}

* This subgroup (A) has been followed for 15 mo. 
TABLE IV

Effect of Delayed Androgen Treatment on IgG Antibodies to Poly A in B/W Female Mice

\begin{tabular}{|c|c|c|c|c|c|c|c|c|c|c|c|c|}
\hline \multirow[b]{2}{*}{ Procedure } & \multirow[b]{2}{*}{ Subgroup } & \multicolumn{11}{|c|}{ Poly $\mathrm{A}$ binding activity at various ages, $m o$} \\
\hline & & 5 & 6 & 7 & 8 & 9 & 10 & 11 & 12 & 13 & 14 & 15 \\
\hline & & \multicolumn{11}{|c|}{ ng Poly AN.2 ml serum } \\
\hline $\begin{array}{l}\text { Sham-operated controls } \\
\text { at } 3 \text { mo }\end{array}$ & $\begin{array}{c}\text { A } \\
\text { B } \\
\text { C } \\
\text { Mean } \pm \text { SD }\end{array}$ & 9 & 16 & $\begin{array}{c}58 \\
24 \\
8 \\
30 \pm 25\end{array}$ & $\begin{array}{c}45 \\
45 \\
38 \\
40 \pm 4\end{array}$ & $\begin{array}{c}38 \\
52 \\
68 \\
53 \pm 15\end{array}$ & $\begin{array}{c}26 \\
50 \\
53 \\
43 \pm 15\end{array}$ & $\begin{array}{c}6 \\
92 \\
65 \\
54 \pm 44\end{array}$ & & & & \\
\hline $\begin{array}{l}\text { Androgen treatment } \\
\text { at } 3 \mathrm{mo}\end{array}$ & $\begin{array}{c}\text { A }^{*} \\
\text { B } \\
\text { C } \\
\text { D } \\
\text { E } \\
\text { F } \\
\text { Mean } \pm S D\end{array}$ & 4 & 3 & $\begin{array}{c}10 \\
40 \\
\\
2 \\
4 \\
0 \\
10 \pm 15\end{array}$ & $\begin{array}{r}15 \\
11 \\
36 \\
7 \\
22 \\
17 \pm 12 \ddagger\end{array}$ & $\begin{array}{c}14 \\
40 \\
35 \\
40 \\
26 \\
27 \pm 19\end{array}$ & $\begin{array}{c}16 \\
13 \\
33 \\
30 \\
8 \\
21 \\
20 \pm 10 \ddagger\end{array}$ & $\begin{array}{c}25 \\
31 \\
13 \\
24 \\
17 \\
30 \\
23 \pm 9\end{array}$ & 98 & 123 & 12 & 34 \\
\hline $\begin{array}{l}\text { Sham-operated controls } \\
\text { at } 6 \mathrm{mo}\end{array}$ & & & & 16 & 21 & 23 & 53 & 55 & & & & \\
\hline $\begin{array}{l}\text { Castration and androgen } \\
\text { treatment at } 6 \text { mo }\end{array}$ & & & & 3 & 8 & 16 & 31 & 42 & 27 & & & \\
\hline
\end{tabular}

* This subgroup (A) has been followed for $15 \mathrm{mo}$.

$\$ P<0.05$.

uranyl acetate and lead citrate. The sections were examined by RCA-EMU (3F and 4; RCA Solid State, Somerville, N. J.) electron microscopes.

Two or more glomeruli were examined from each specimen. Low magnification $(\times 800)$ negatives were taken of each glomerulus and $\times 4$ photographic enlargements were printed for study. Additional micrographs at magnifications between 2,000 and 4,000 were also taken and enlarged $\times 4$ for more detailed examination. These prints were independently evaluated by two investigators who have had many years of experience examining electron micrographs of experimental animals and human renal glomeruli.

The degree of involvement by electron dense deposits was judged on a scale of 0 to +6 . In addition to the evaluation of the extent of the electron dense deposits, their distribution in the mesangial area and on the subendothelial and epithelial sides of the basement membrane were noted. Also, morphological changes in the thickness of the basement membrane, coalescence of the foot processes of the epithelial cells, pos-

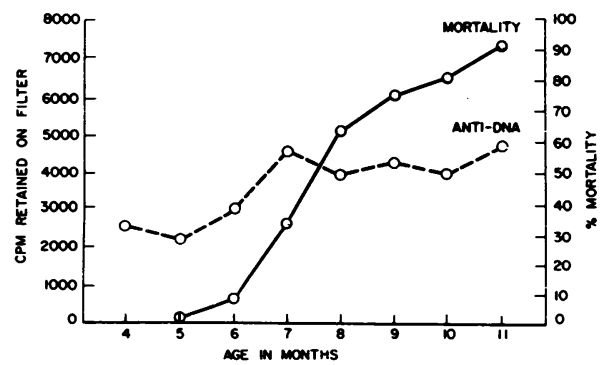

FIGURE 1 Relationship of mortality and antibodies to DNA in sham (control) B/W female mice. This represents subgroup A of sham-operated controls at 3 mo. sible cell proliferation, and occlusion of capillary lumen were all noted. The two assessments were compared and a single report made. After that, the protocol code was broken and the correlations made.

\section{RESULTS}

Survival and antibodies to nucleic acids. The cumulative mortality in sham-treated $\mathrm{B} / \mathrm{W}$ female mice compared to animals started on androgen at the age of 3 mo is shown in Table I. There was an increasing mortality in the sham group, commencing at 6 mo of age. At $11 \mathrm{mo}, 89 \%$ of the sham-operated animals had died, compared to $26 \%$ of the hormone-treated animals (Table I). In animals treated at 6 mo of age, $80 \%$ of the sham-operated controls had died by 11 mo of age, compared to none of the hormone-treated mice (Table II).

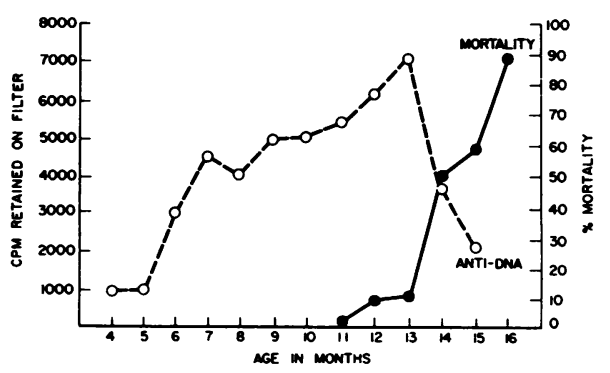

FIGURE 2 Relationship of mortality and antibodies to DNA in androgen-treated $B / W$ female mice. This represents subgroup $A$ of androgen treatment at 3 mo. 


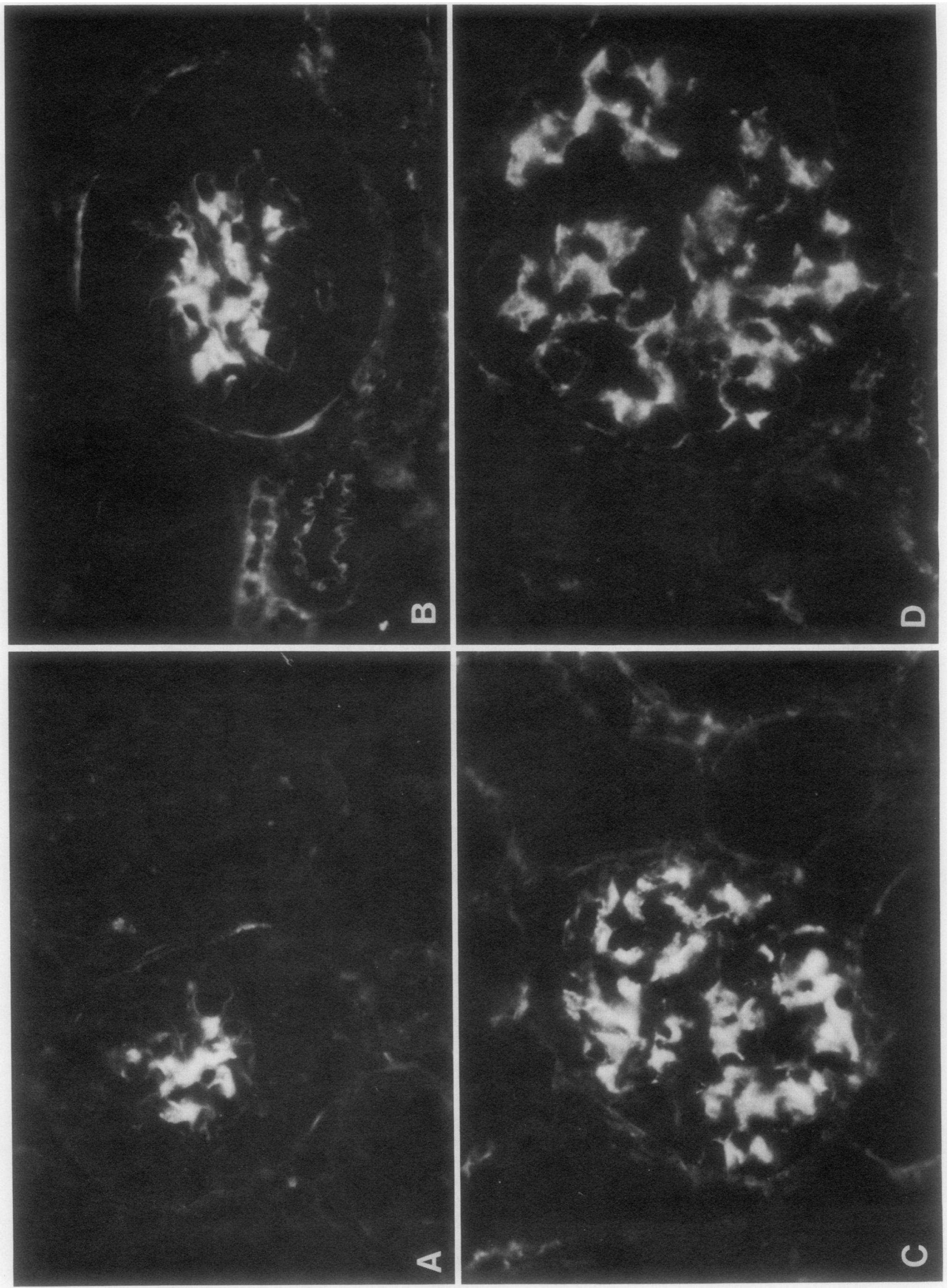


In spite of this great difference in mortality between sham and the two androgen-treated groups, there was essentially no difference in the formation of either IgM or IgG antibodies to DNA. The similar age-dependent development of IgG antibodies to DNA in the sham and androgen-treated groups is illustrated in Table III. There was also a general uniformity between subgroups, and no significant difference between the means of sham and androgen-treated groups (Table III).

In contrast to anti-DNA, there was a difference in the formation of IgG antibodies to polyadenylic acid between the sham and experimental groups. These antibodies were decreased in the androgen-treated mice compared to the sham animals (Table IV).

A comparison of anti-DNA antibody and mortality is shown for one sham-treated control subgroup of $B / W$ mice in Fig. 1. There is a rise in anti-DNA from 5 to $7 \mathrm{mo}$ of age associated with a steep increase in mortality from 6 to 8 mo of age. A similar plot for one subgroup receiving androgen from the age of 3 mo shows a striking contrast (Fig. 2). The high concentrations of antiDNA present from 6 to 13 mo are not associated with mortality. These animals survive even though they have high levels of IgG antibodies to DNA.

Renal histopathology. Sham and androgen-treated mice were sacrificed at monthly intervals, starting at $6 \mathrm{mo}$, for examination of renal histopathology. Androgen-treated mice had less evidence of immune complex glomerulonephritis when compared to the control group as determined by light, immunofluorescent, and electron microscopy. Sham animals had greater immunofluorescent staining for Ig and C3 in the glomeruli in comparison with either of the androgen-treated groups (Figs. 3 and 4 ).

By electron microscopy, sham mice had multiple electron-dense deposits in mesangial areas extending to peripheral portions of capillaries (Fig. 5). The androgen-treated mice had significantly fewer electrondense deposits, with only occasional mesangial areas involved (Fig. 6).

Comparison of antibodies to nucleic acids and glomerular immunofluorescence in individual mice. Three sham mice and three mice treated with androgen at 3 mo were studied individually at 9 mo to compare autoantibody levels with glomerular immunoglobulin deposition (Table V). The sham animals had large amounts of IgM and IgG antibodies to DNA and Poly $A$, and three to five plus glomerular immunofluorescence. The treated mice had equally large amounts of antibody to DNA, much less antibody to Poly A, and only one to three plus glomerular immunofluorescence.

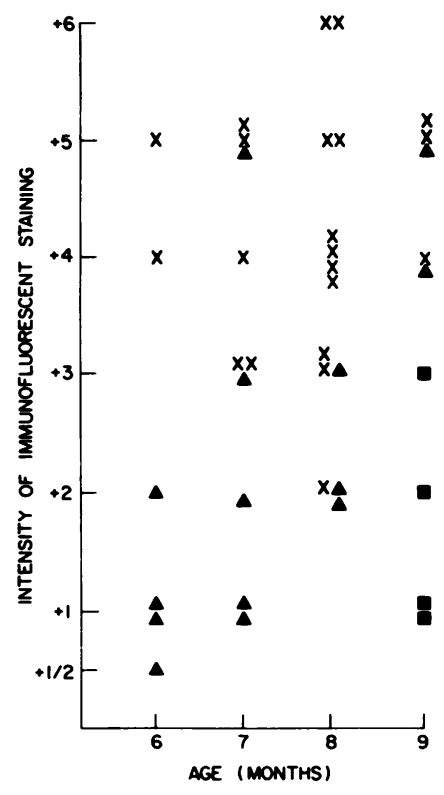

FIGURE 4 Immunoglobulin deposition is renal glomeruli in sham $(x)$ and androgen treated NZB/NZW female mice ([A] androgen at $3 \mathrm{mo} ;[\square]$ androgen and castration at $6 \mathrm{mo}$ ).

\section{DISCUSSION}

The ability of sex hormones to modulate the expression of autoimmunity in $\mathrm{B} / \mathrm{W}$ mice has been clearly demonstrated (5-8). The published studies were performed in young animals before the onset of autoimmune disease. In general, they demonstrate that androgens suppress and estrogens accelerate autoantibody formation, immune complex nephritis, and mortality. They offer an explanation for the female predominance of systemic lupus erythematosus (SLE) and support current pathogenetic concepts which suggest that antibodies to DNA are causally related to the immune complex nephritis.

In our previous studies, prepubertal castration of female $\mathrm{B} / \mathrm{W}$ mice in the absence of androgen administration had no significant effect on antibodies to DNA or mortality (5). However, when prepubertal castration was combined with the administration of androgen starting at $2 \mathrm{wk}$ of age, there was a significant reduction in antibodies to DNA, decrease in immune complex glomerular deposits, and prolongation of survival (6). In these young mice, some effects of castration did not occur if neonatal thymectomy was also performed. These results suggested that sex hormones modulate autoimmunity, at least in part, by thymic-

FIGURE 3 Indirect immunofluorescence of renal glomeruli of female $B / W$ mice with polyvalent anti-mouse Ig showing: (A) 7 mo old treated with androgen from 3 mo of age (one plus); (B) 9 mo old castrated and treated with androgen at 6 mo of age (two plus); (C) 7 mo old sham-treated control (three plus); and (D) 9 mo old sham-treated control (four plus). 


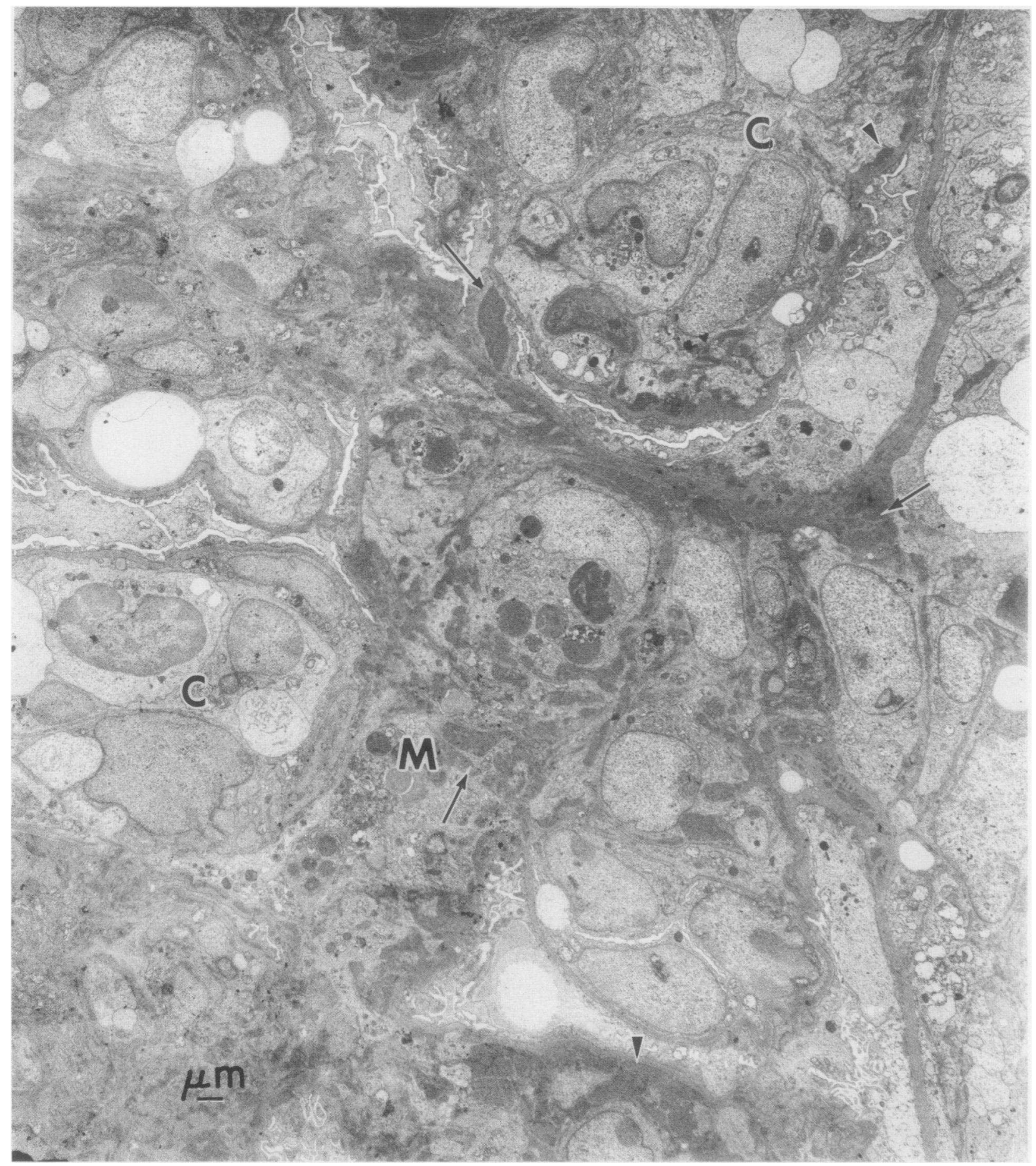

Figure 5 A glomerulus of a sham-operated 6-mo-old female. There are many congested capillaries $(\mathrm{C})$, and the mesangial $(\mathbf{M})$ areas are enlarged and contain many deposits of electron-dense material (arrows). In some areas (arrow heads) the deposits are beginning to appear on the endothelial side of the basement membrane of capillary loops away from the mesangial area.

dependent mechanisms capable of regulating autoantibody production (6).

In the present studies, androgen treatment was delayed to an age just before ( $3 \mathrm{mo})$ or during $(6 \mathrm{mo})$ active autoimmune disease. We again observed less immune complex nephritis and a prolonged survival. 




Figure 6 A glomerulus from a 6-mo-old female treated with androgen from 3 mo of age. It is nearly normal in appearance with many patent capillaries $(C)$, with an occasional deposition of electron-dense material (arrows) in mesangial (M) areas.

However, to our surprise and contrary to previous studies, there was no significant reduction in antibodies to DNA in these animals. Thus, when androgen treatment is delayed, the hormone appears to achieve its therapeutic effect through mechanisms that do not directly involve anti-DNA formation. By contrast, antibodies to Poly $\mathrm{A}$ are decreased by delayed androgen treatment. As the treated mice age, antibodies to Poly A appear and mortality increases.

Androgens are known to augment the serum concentrations of several complement components in mice, including the analogue of human $\mathrm{C} 4$ (Ss), the sexlimited protein variant of Ss (Slp), C5, C6, and Ssbinding protein (10). Ss is lower in females than in 
TABLE V

Comparison of Autoantibodies and Glomerular Immunofluorescence in Individual Mice

\begin{tabular}{|c|c|c|c|}
\hline \multirow[b]{2}{*}{ Procedure } & \multicolumn{2}{|c|}{$\begin{array}{l}\text { IgG anti-nucleic acid } \\
\text { binding activity }\end{array}$} & \multirow{2}{*}{$\begin{array}{l}\text { Immunofluorescent } \\
\text { staining intensity }\end{array}$} \\
\hline & DNA & Poly A & \\
\hline \multicolumn{4}{|c|}{$\mathrm{ng} / 0.2 \mathrm{ml}$ serum } \\
\hline \multirow[t]{3}{*}{ Sham } & 39 & 16 & +3 \\
\hline & 53 & 47 & +4 \\
\hline & 25 & 126 & +5 \\
\hline \multirow{3}{*}{$\begin{array}{l}\text { Androgen } \mathrm{Rx} \\
\text { at } 3 \mathrm{mo}\end{array}$} & 50 & 14 & +1 \\
\hline & 25 & 0 & +1 \\
\hline & 44 & 0 & +3 \\
\hline
\end{tabular}

males. Slp is only present in certain strains, and then only in the males. When these adult males are castrated, the Slp levels gradually fall to zero (11). When males are castrated before sexual maturity, Slp does not appear unless mice are injected with testosterone. Moreover, the administration of testosterone to female mice genetically capable of expressing Slp induces its expression in concentrations equivalent to those seen in males of the same strain.

The testicular feminization mutant is an X-linked recessive mutation, which renders mice unresponsive to testosterone. The introduction of testicular feminization mutant into mice expressing Slp totally suppresses its expression (11). These results indicate a role for androgen in the regulation of expression of the Slp allotype.

A recently characterized mouse serum protein with a specific binding affinity for $\mathrm{Ss}$ is also testosterone dependent (11): Levels of this Ss-binding protein are lower in female than in male mice. Castration of male mice reduces Ss-binding protein, whereas the administration of testosterone increases its expression.

In humans, androgens are therapeutic in hereditary angioneurotic edema, a disease associated with a deficiency of the $\mathrm{Cl}$ esterase inhibitors (12). The administration of androgen or danazol (13), a synthetic weakly androgenic substance, causes $\mathrm{Cl}$ inhibitor levels to rise to normal values. There is an accompanying rise in $\mathrm{C4}$, and a marked reduction in clinical attacks.

Androgens probably modulate autoimmunity in B/W mice through more than one mechanism. In the current experiments, in which mice showed less immune complex deposition and prolonged survival in the face of high levels of anti-DNA antibodies, an effect of androgen on the complement system may be responsible. For example, an androgen-induced rise in certain complement components might result in decreased formation or more efficient clearance of circulating immune complexes. An abnormal clearance of sensitized erythrocytes has been demonstrated in SLE (14). A more effective clearance of immune complexes brought about by androgen could reduce their deposition in the glomerular capillary network and reduce nephritis without changing autoantibody levels. $\mathrm{B} / \mathrm{W}$ mice in whom androgen treatment is delayed might serve as an important laboratory model for study of the complicated mechanisms involved in the pathogenesis of lupus nephritis. Patients with SLE who have large amounts of antibodies to DNA and yet minimal or no evidence of significant renal disease may represent a clinical parallel to the situation reported here.

The therapeutic results achieved with delayed androgen suggest that hormone modulation of autoimmunity might hold promise for the treatment of SLE, even in patients with active disease. Experiments currently underway are designed to determine the best therapeutic approach applicable to human investigation.

\section{ACKNOWLEDGMENTS}

We gratefully acknowledge the technical assistance of Ms. Jackie Sadakian, Ms. Carmen White, Ms. Grace Cheung, and Mr. Robert Surface, and the help of Mr. Daniel Lechay in preparation of the manuscript.

This work was supported by the Medical Research Service of the Veterans Administration, by U. S. Public Health Service grant AM 1640, by a grant from the Kroc Foundation, and a contract from the State of California.

\section{REFERENCES}

1. Howie, J. B., and B. J. Helyer. 1968. The immunology and pathology of NZB mice. Adv. Immunol. 9: 215-266.

2. Warner, N. L. 1977. Genetic aspects of autoimmune disease in animals. In Autoimmunity: Genetic, Immunologic, Virologic and Clinical Aspects. N. Talal, editor. Academic Press, Inc., New York. 33-62.

3. Levy, J. A. 1977. C-type RNA viruses and autoimmune disease. In Autoimmunity: Genetic, Immunologic, Virologic and Clinical Aspects. N. Talal, editor. Academic Press, Inc., New York. 404-456.

4. Talal, N. 1970. Immunologic and viral factors in the pathogenesis of systemic lupus erythematosus. Arthritis Rheum. 13: 887-893.

5. Roubinian, J. R., R. Papoian, and N. Talal. 1977. Androgenic hormones modulate autoantibody responses and improve survival in murine lupus. J. Clin. Invest. 59: 1066-1070.

6. Roubinian, J. R., N. Talal, J. S. Greenspan, J. R. Goodman, and P. K. Siiteri. 1978. Effect of castration and sex hormone treatment on survival, anti-nucleic acid antibodies, and glomerulonephritis in NZB/NZW $F_{1}$ mice. J. Exp. Med. 147: 1568-1583.

7. Tonietti, G., P. H. Lambert, and L. Accinni. 1975. Influenza degli ormoni sessuali sulle manifestazioni autoimmuni dei topi New Zealand NZB $\times \mathrm{WF}_{1}$. Folia Allergol. Immunol. Clin. 22: 143-151.

8. Raveche, E. S., L. W. Klassen, and A. D. Steinberg. 1976. Sex differences in formation of anti-T-cell antibodies. Nature (Lond.). 263: 415-416. 
9. Attias, M. R., R. A. Sylvester, and N. Talal. 1973. Filter radioimmunoassay for antibodies to reovirus RNA in systemic lupus erythematosus. Arthritis Rheum. 16: 719725.

10. Ferreira, A., M. Takahashi, and V. Nussenzweig. 1977. Purification and characterization of mouse serum protein with specific binding affinity for $\mathrm{C} 4$ (Ss protein). J. Exp. Med. 146: 1001-1018.

11. Shreffler, D. C. 1976. The S region of the mouse major histocompatibility complex (H-2): genetic variation and functional role in complement system. Transplant. Rev. 32: $140-167$.
12. Donaldson, V. H., and R. R. Evans. 1963. A biochemical abnormality in hereditary angioneurotic edema: absence of serum inhibitor of C'l-esterase. Am. J. Med. 35: 37-44.

13. Gelfand, J. A., R. J. Sherins, D. W. Alling, and M. M. Frank. 1976. Treatment of hereditary angioedema with danazol. Reversal of clinical and biochemical abnormalities. $N$. Engl. J. Med. 295: 1444-1448.

14. Frank, M. M., C. J. Jaffe, R. P. Kimberly, T. J. Lawley, and P. H. Plotz. 1977. An immunospecific clearance defect in patients with systemic lupus erythematosus (SLE) related to the levels of circulating immune complexes (IC). Clin. Res. 25: 357A. (Abstr.) 